\title{
Predicting the present-day in situ stress distribution within the Yanchang Formation Chang 7 shale oil reservoir of Ordos Basin, central China
}

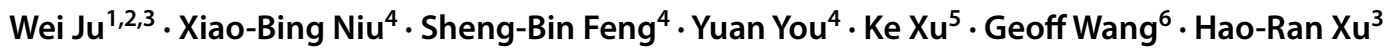

Received: 27 August 2019 / Published online: 22 April 2020

(c) The Author(s) 2020

\begin{abstract}
The Yanchang Formation Chang 7 oil-bearing layer of the Ordos Basin is important in China for producing shale oil. The present-day in situ stress state is of practical implications for the exploration and development of shale oil; however, few studies are focused on stress distributions within the Chang 7 reservoir. In this study, the present-day in situ stress distribution within the Chang 7 reservoir was predicted using the combined spring model based on well logs and measured stress data. The results indicate that stress magnitudes increase with burial depth within the Chang 7 reservoir. Overall, the horizontal maximum principal stress $\left(S_{\mathrm{Hmax}}\right)$, horizontal minimum principal stress $\left(S_{\mathrm{hmin}}\right)$ and vertical stress $\left(S_{\mathrm{v}}\right)$ follow the relationship of $S_{\mathrm{v}} \geq S_{\mathrm{Hmax}}>S_{\mathrm{hmin}}$, indicating a dominant normal faulting stress regime within the Chang 7 reservoir of Ordos Basin. Laterally, high stress values are mainly distributed in the northwestern parts of the studied region, while low stress values are found in the southeastern parts. Factors influencing stress distributions are also analyzed. Stress magnitudes within the Chang 7 reservoir show a positive linear relationship with burial depth. A larger value of Young's modulus results in higher stress magnitudes, and the differential horizontal stress becomes higher when the rock Young's modulus grows larger.
\end{abstract}

Keywords Present-day in situ stress · Chang 7 shale oil reservoir · Influencing factor · Ordos Basin · Stress distribution prediction $\cdot$ Yanchang Formation

\section{Introduction}

Edited by Jie Hao

Wei Ju

wju@cumt.edu.cn

1 Key Laboratory of Coalbed Methane Resources and Reservoir Formation Process, Ministry of Education, China University of Mining and Technology, Xuzhou 221008, Jiangsu, China

2 Shandong Provincial Key Laboratory of Depositional Mineralization and Sedimentary Mineral, Shandong University of Science and Technology, Qingdao 266590, Shandong, China

3 School of Resources and Geosciences, China University of Mining and Technology, Xuzhou 221116, Jiangsu, China

4 Institute of Exploration and Development, PetroChina Changqing Oilfield Company, Xi' an 710018, Shaanxi, China

5 PetroChina Tarim Oilfield Company, Korla 841000, Xinjiang, China

6 School of Chemical Engineering, The University of Queensland, Brisbane, Queensland 4072, Australia
With the continued development of hydrocarbon theories and recent exploration practices, the global oil and gas industry has gotten into the period of unconventional hydrocarbon resources. The unconventional shale oil and gas, tight oil and gas, gas hydrates and coalbed methane have shown great potential under the present-day economic and technological conditions, and their production has changed the global energy consumption structure (Jia et al. 2012; Zou et al. 2013; Vedachalam et al. 2015). Among those unconventional resources, shale oil is defined as a kind of nongaseous hydrocarbon with great exploration and development potential, which is generally accumulated in mudstone and shale layers in multiple states (Zhang et al. 2012, 2015; Zou et al. 2013).

In the past several years, commercial development of shale oil was successfully obtained in many countries of the world, e.g., the USA, Canada and Australia (Zhou et al. 2019). In China, shale oil resources are abundant, and they are widely distributed in the Mesozoic-Cenozoic continental 
basins, including the Songliao Basin, Junggar Basin, Ordos Basin, Qiangtang Basin, Bohai Bay Basin and Qaidam Basin (Yang et al. 2013, 2018; Zhang et al. 2015; Sun 2017; Zhou et al. 2017). In the Ordos Basin, shale oil resources are largely accumulated in the Yanchang Formation Chang 7 oil-bearing layer, and the estimated amount is more than $10 \times 10^{8}$ tons (Yang et al. 2013).

Generally, shale oil resources are dispersed over large areas, have lower concentrations and require well stimulation or additional extraction technology (Zou et al. 2013). Hydraulic fracturing is an important approach for shale oil development. During hydraulic fracturing operations in unconventional hydrocarbon reservoirs, the present-day in situ stress state is a critical factor that should be taken into account (Bell 1996; Tingay et al. 2009; Schmitt et al. 2012; Ju et al. 2018). In addition, knowledge of present-day stress field indicates important effects on wellbore stability and reservoir management (Zoback et al. 2003; Binh et al. 2007; Tingay et al. 2009; Rajabi et al. 2016; Ju et al. 2017, 2019). Hence, a better understanding of the present-day in situ stress state will definitely help the exploration and development of shale oil resources. However, few previous studies are carried out focusing on the present-day stress state in the Yanchang Formation Chang 7 oil-bearing layer, which limits the further exploration and development of shale oil in the Ordos Basin.

The objective of this study is to predict the present-day in situ stress distribution within the Yanchang Formation Chang 7 shale oil reservoir and analyze the influencing factors. The results are expected to bring new geological references for shale oil production in the Ordos Basin.

\section{Geological setting}

The Ordos Basin is the second-largest sedimentary basin in China, which has experienced a complex geological history. The present-day geomorphology indicates that the central part of the Ordos Basin is relatively stable, whereas the margins have undergone strong tectonic activities, resulting in structural complexity (Fig. 1; Zeng and Li 2009; Yang et al. 2012; Lyu et al. 2016; Ju et al. 2020). Within the Ordos Basin, large volumes of unconventional petroleum resources are accumulated in the Upper Triassic Yanchang Formation (Zeng and Li 2009; Ju et al. 2015; Zhang et al. 2015; Cui et al. 2019). The Yanchang Formation are generated in a lake-delta sedimentary system, and it can be divided into ten oil-bearing layers, known as the Chang 10 to Chang 1 oil-bearing layer from bottom to top, based on sedimentary cycle, rock associations, log characteristics and oil-bearing properties of the deposits (Fig. 2; Yang et al. 2012, 2016). The development of the Ordos lake basin gets its peak during the deposition of Chang 7 oil-bearing layer, and mudstone and shale layers of deep and semi-deep lake facies are widely distributed (Fu et al. 2015; Zhang et al. 2015; Yang et al. 2016). In addition, the Chang 7 oil-bearing layer can be further divided into the Chang $7_{1}$, Chang $7_{2}$ and Chang $7_{3}$ sublayers.

Generally, based on the differences in sedimentary structure, rock composition and TOC content, mudstones and shales in the Yanchang Formation Chang 7 oil-bearing layer of Ordos Basin can be divided into two types: black shales and dark mudstones (Fu et al. 2015; Yang et al. 2016). Laterally, the Chang 7 shale is widely distributed with variable thickness (Cui et al. 2019), and shale oil within the Chang 7 oil-bearing layer is mainly distributed in the Dingbian-Ansai-Huangling-Changwu-Pingliang-Huanxian regions (Fig. 3; Fu et al. 2015; Yang et al. 2016). Vertically, black shales are mainly in the Chang $7_{3}$ sublayer, whereas dark mudstones are widely distributed in all three sublayers. The development scale of mudstones and/or shales greatly varies in different areas.

\section{In situ stress tensor}

The present-day in situ stress state can be described by the stress tensor, which includes the orientation and magnitudes of three orthogonal principal stresses (Engelder 1993). In general, the stress tensor may be reduced to four components, namely the magnitudes of horizontal maximum principal stress $\left(S_{\mathrm{Hmax}}\right)$, horizontal minimum principal stress $\left(S_{\mathrm{hmin}}\right)$ and vertical stress $\left(S_{\mathrm{v}}\right)$, and the orientation of horizontal stresses (Bell 1996; Zoback et al. 2003; Ju et al. 2017).

In addition, based on the relative magnitudes of $S_{\mathrm{Hmax}}$, $S_{\text {hmin }}$ and $S_{\mathrm{v}}$, three stress regimes are divided (Anderson 1951; Fig. 4):

(i) normal faulting stress regime $\left(S_{\mathrm{v}}>S_{\mathrm{H} \max }>S_{\mathrm{hmin}}\right)$,

(ii) strike-slip faulting stress regime $\left(S_{\mathrm{H} \max }>S_{\mathrm{v}}>S_{\mathrm{hmin}}\right)$, and

(iii) thrust faulting stress regime $\left(S_{\mathrm{H} \max }>S_{\mathrm{hmin}}>S_{\mathrm{v}}\right)$.

\section{Methodology}

\subsection{Rock mechanics}

Knowledge of rock mechanics is critical for accurately predicting the present-day in situ stress distribution (BrookeBarnett et al. 2015; Ju et al. 2017). Generally, rock mechanics experiment is an important and accurate approach to obtain the mechanics parameters (e.g., Young's modulus, Poisson's ratio), and the measured mechanics properties are static ones; however, this approach has its limitations: (i) 


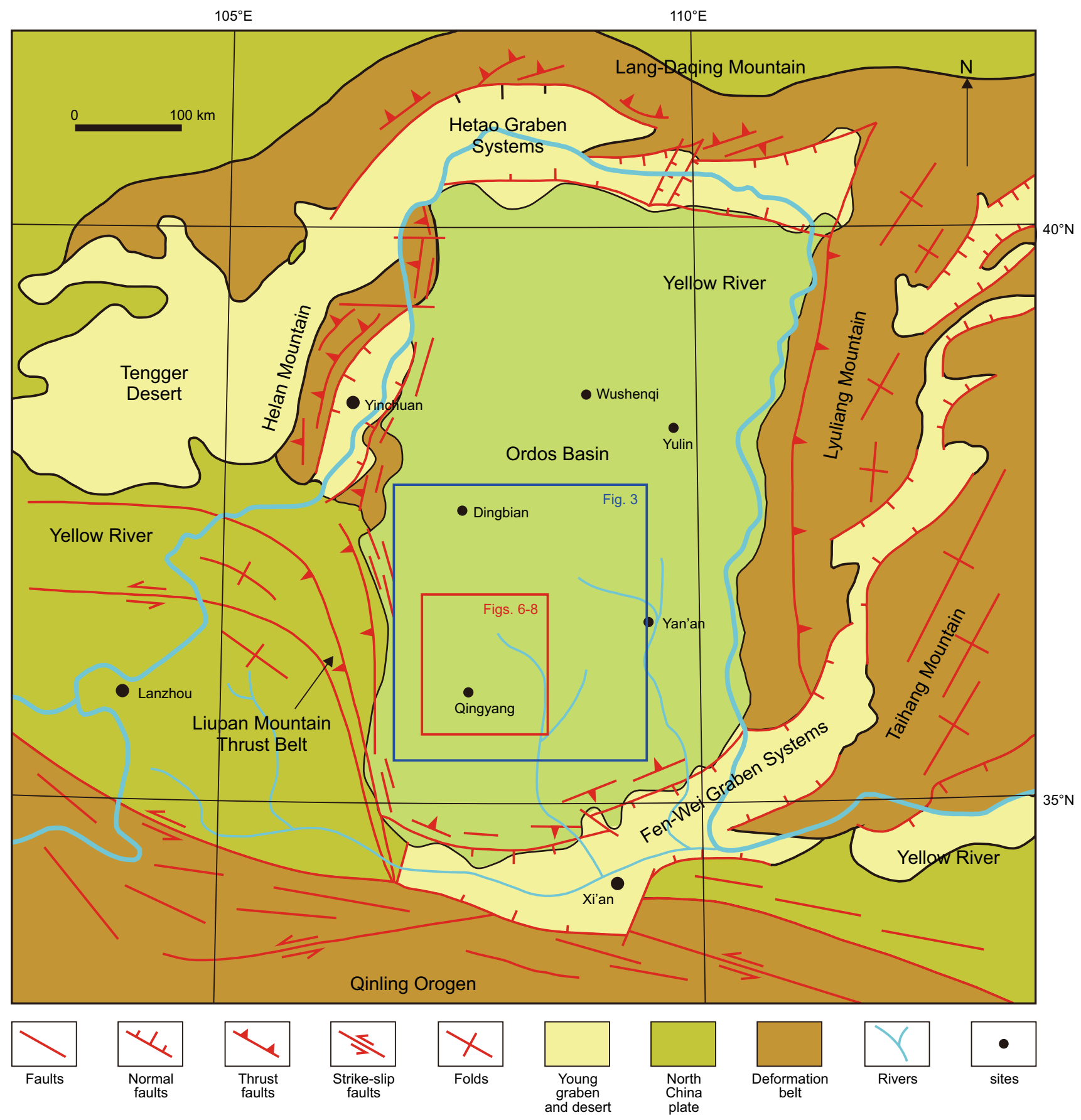

Fig. 1 Simplified regional geological map of the Ordos Basin in central China (modified after Ritts et al. 2004; Ju et al. 2015)

The collection of core samples is not continuous, resulting in the discrete rock mechanics parameters along with burial depth; (ii) it is money- and time-consuming.

Dynamic velocity-based mechanics properties are easy to calculate based on well logs (Eqs. 1 and 2; Binh et al. 2007; Fjaer et al. 2008; Brooke-Barnett et al. 2015), and more importantly, they are continuous along with burial depth. Hence, continuous static mechanics parameters can be obtained from dynamic data by building the relationship between them.

Dynamic Poisson's ratio:

$$
\mu_{\mathrm{d}}=\frac{2-\left(v_{\mathrm{p}} / v_{\mathrm{s}}\right)^{2}}{2\left(1-\left(v_{\mathrm{p}} / v_{\mathrm{s}}\right)^{2}\right)}
$$




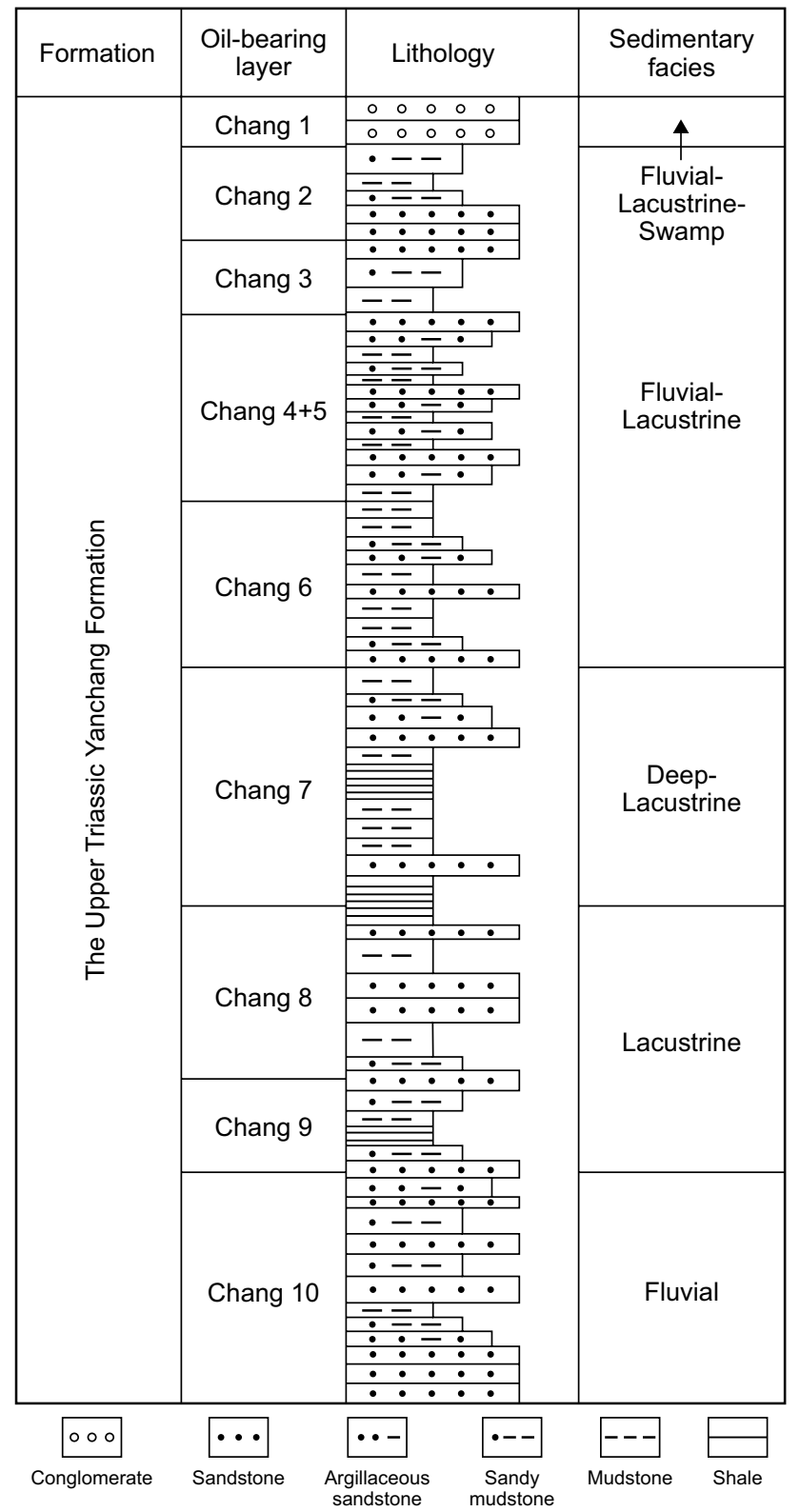

Fig. 2 Generalized stratigraphy of the Upper Triassic Yanchang Formation in the Ordos Basin

Dynamic Young's modulus:

$E_{\mathrm{d}}=\frac{\rho v_{\mathrm{s}}^{2}\left(3 v_{\mathrm{p}}^{2}-4 v_{\mathrm{s}}^{2}\right)}{v_{\mathrm{p}}^{2}-v_{\mathrm{s}}^{2}}$

where $v_{\mathrm{p}}$ and $v_{\mathrm{s}}$ are the compressional and shear wave velocity, respectively, $\rho$ is the density from bulk density logs, $E_{\mathrm{d}}$ is the dynamic Young's modulus, and $\mu_{\mathrm{d}}$ is the dynamic Poisson's ratio.

\subsection{Method for predicting stress distribution}

In general, the $S_{\mathrm{v}}$ is the simplest to calculate based on Eq. 3, which is the integration of rock densities from the surface to a particular depth (Zoback et al. 2003; Brooke-Barnett et al. 2015; Ju et al. 2017).

$S_{\mathrm{v}}=\int_{0}^{h} \rho(h) g \mathrm{~d} h$

where $S_{\mathrm{v}}$ is the vertical stress, $g$ is the gravitational acceleration, $\rho(h)$ is the density of the overburden rock as a function of burial depth, and $h$ indicates the burial depth from the surface to a particular depth.

In most regions including the Ordos Basin, density logs are not acquired from the ground level. Hence, in this study, an extrapolation method was used here and a stress gradient of approximately $23 \mathrm{kPa} / \mathrm{m}$ was identified in the open hole section to determine the $S_{\mathrm{v}}$ magnitude.

For horizontal stresses, there are various models to calculate their magnitudes, which are generally categorized into the uniaxial strain mode and anisotropic mode (Table 1). The uniaxial strain mode assumes that horizontal stress is caused by the weight of overlying strata; hence, the $S_{\mathrm{Hmax}}$ and $S_{\mathrm{hmin}}$ are the same in magnitude. However, the above assumption does not match the measured results of in situ stresses in most sedimentary basins (Yin et al. 2017).

In this study, the combined spring model (Thiercelin and Plumb 1994; Li and Zhang 1997; Table 1), a commonly used anisotropic mode, was selected to analyze horizontal in situ stresses within the Yanchang Formation Chang 7 shale oil reservoir of Ordos Basin. The combined spring model has two main advantages: (i) The strata are regarded as anisotropic, and (ii) the effects of both Young's modulus and Poisson's ratio are taken into account.

\subsection{Pore pressure calculation}

Pore pressure is an important parameter for calculating horizontal stresses as obviously seen from the models listed in Table 1. Pore pressure can be divided into types of abnormally low pressure, normal pressure, abnormally high pressure and ultrahigh pressure based on pressure coefficient and/or pressure gradient (Du et al. 1995; Table 2).

Eaton's method (Eaton 1972) for pore pressure prediction can be made from either velocity or resistivity measurements in the well. The following equation (Eq. 4) indicates the empirical equation from the sonic compressional transit time.

$P_{\mathrm{o}}=S_{\mathrm{v}}-\left(S_{\mathrm{v}}-P\right)\left(\frac{\Delta t_{\mathrm{n}}}{\Delta t}\right)^{n}$ 

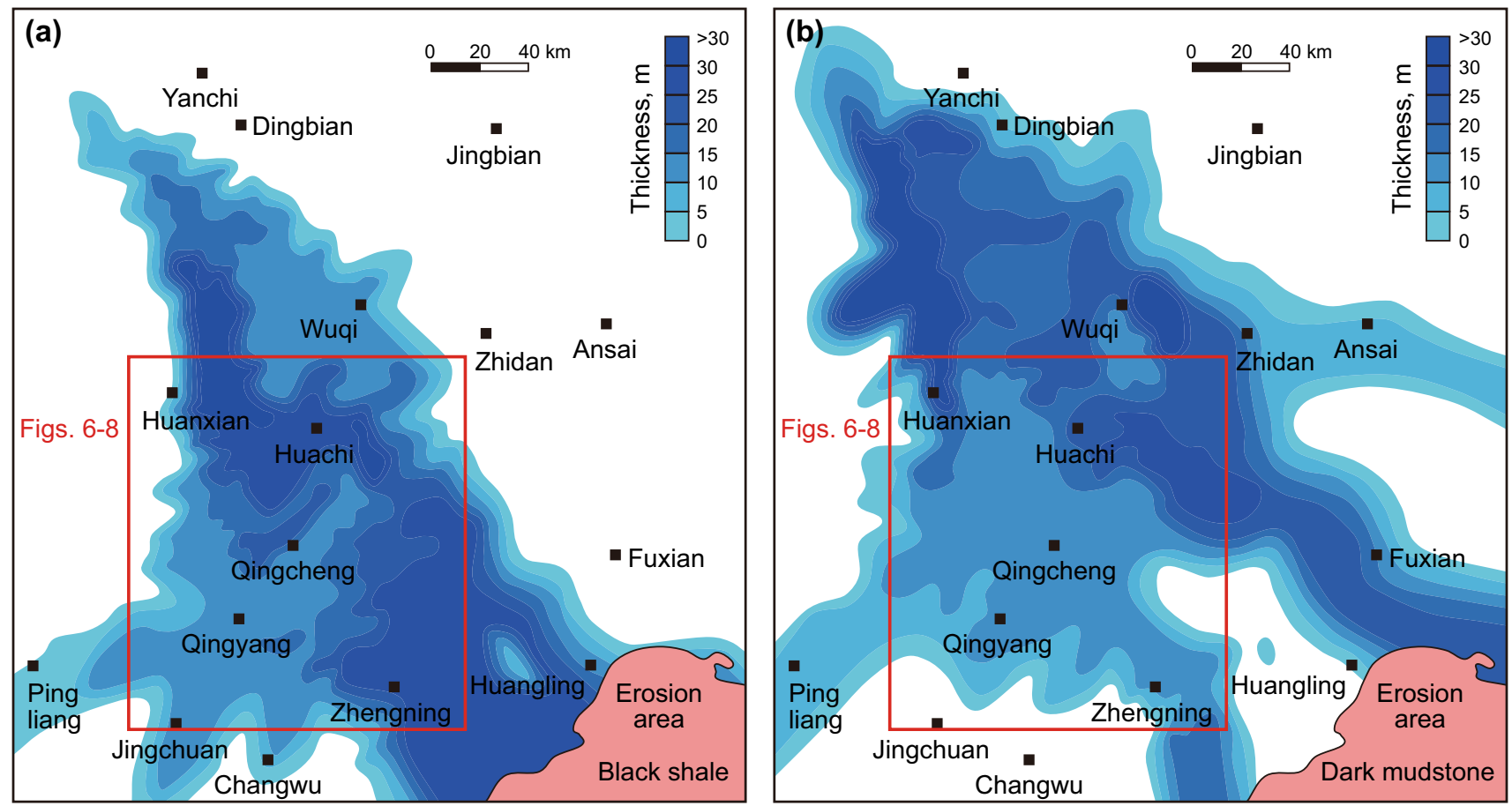

Fig. 3 The thickness map showing the Yanchang Formation Chang 7 black shale (a) and dark mudstone (b) in the Ordos Basin (after Fu et al. 2015; Yang et al. 2016)
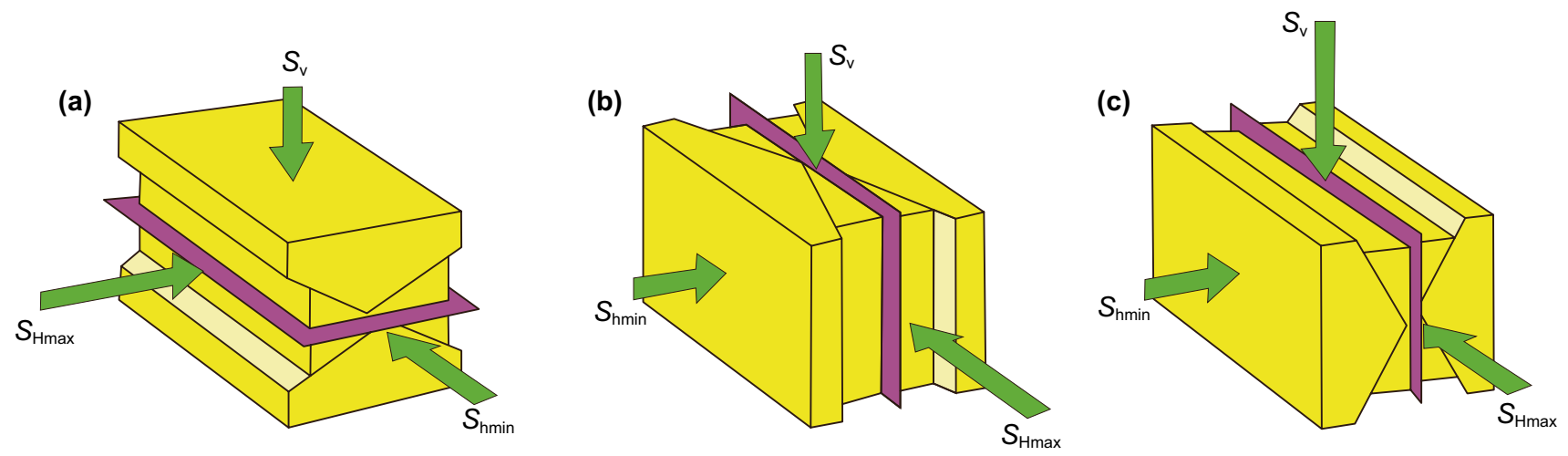

Fig. 4 Schematic illustration showing the types of in situ stress regime based on Anderson's classification (after Brooke-Barnett et al. 2015; Ju et al. 2017). a thrust faulting stress regime, $\mathbf{b}$ strike-slip faulting stress regime and $\mathbf{c}$ normal faulting stress regime. The pink plane indicates the orientation of a propagated hydraulic fracture in the associated stress regime

where $P_{\mathrm{o}}$ is pore pressure, $S_{\mathrm{v}}$ is the vertical stress, $P$ is the hydrostatic pore pressure, $\Delta t_{\mathrm{n}}$ is the sonic transit time or slowness at the normal pressure, $\Delta t$ is the sonic transit time obtained from $\operatorname{logs}$, and $n$ is an exponent.

\section{Parameters for stress distribution prediction}

\subsection{Relationships between static and dynamic mechanics parameters}

Based on measurements from rock mechanics experiments and calculations from well logs (Table 3), the relationships between static and dynamic Poisson's ratio and Young's modulus are shown as Eqs. 5 and 6, respectively. 
Table 1 Empirical models for calculating in situ stress magnitude

\begin{tabular}{|c|c|c|c|}
\hline Model name & Empirical model expression & Characteristics & References \\
\hline \multicolumn{4}{|l|}{$\begin{array}{l}\text { Uniaxial strain } \\
\text { mode }\end{array}$} \\
\hline Dinnik model & $S_{\mathrm{H} \max }=S_{\mathrm{hmin}}=\frac{\mu}{1-\mu} S_{\mathrm{v}}$ & $\begin{array}{l}\text { For homogeneous and isotropic } \\
\text { layers without pore pressure }\end{array}$ & Dinnik (1925) \\
\hline $\begin{array}{l}\text { Matthews and Kelly } \\
\text { model }\end{array}$ & $S_{\mathrm{H} \max }=S_{\mathrm{h} \min }=K\left(S_{\mathrm{v}}-P_{\mathrm{o}}\right)+P_{\mathrm{o}}$ & $\begin{array}{l}\text { Obtained from hydraulic fracturing } \\
\text { with pore pressure, but } K \text { is hard } \\
\text { to determine }\end{array}$ & $\begin{array}{l}\text { Matthews and Kelly } \\
\text { (1967) }\end{array}$ \\
\hline Eaton model & $S_{\mathrm{H} \max }=S_{\mathrm{hmin}}=\frac{\mu}{1-\mu}\left(S_{\mathrm{v}}-P_{\mathrm{o}}\right)+P_{\mathrm{o}}$ & $K=\frac{\mu}{1-\mu}$ & Eaton (1969) \\
\hline Anderson model & $S_{\mathrm{H} \max }=S_{\mathrm{h} \min }=\frac{\mu}{1-\mu}\left(S_{\mathrm{v}}-P_{\mathrm{o}}\right)+\alpha P_{\mathrm{o}}$ & Biot coefficient () is introduced & $\begin{array}{l}\text { Anderson et al. } \\
\text { (1973) }\end{array}$ \\
\hline Newberry model & $S_{\mathrm{H} \max }=S_{\mathrm{h} \min }=\frac{\mu}{1-\mu}\left(S_{\mathrm{v}}-\alpha P_{\mathrm{o}}\right)+P_{\mathrm{o}}$ & $\begin{array}{l}\text { For low porosity and low perme- } \\
\text { ability layers with microfractures }\end{array}$ & $\begin{array}{l}\text { Newberry et al. } \\
\text { (1985) }\end{array}$ \\
\hline \multicolumn{4}{|l|}{ Anisotropic mode } \\
\hline Huang model & $\begin{array}{l}S_{\mathrm{H} \max }=\left(\frac{\mu}{1-\mu}+\beta_{1}\right)\left(S_{\mathrm{v}}-\alpha P_{\mathrm{o}}\right)+\alpha P_{\mathrm{o}} \\
S_{\mathrm{hmin}}=\left(\frac{\mu}{1-\mu}+\beta_{2}\right)\left(S_{\mathrm{v}}-\alpha P_{\mathrm{o}}\right)+\alpha P_{\mathrm{o}}\end{array}$ & $\begin{array}{l}\text { The tectonic stress coefficient } \\
\text { is introduced, but the effect of } \\
\text { Young's modulus is ignored }\end{array}$ & Huang (1984) \\
\hline $\begin{array}{l}\text { Combined spring } \\
\text { model }\end{array}$ & 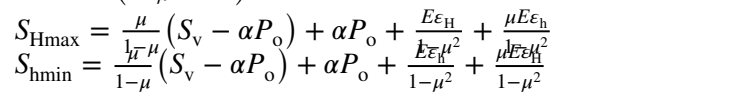 & Horizontal deformation is constant & $\begin{array}{l}\text { Thiercelin and Plumb } \\
\text { (1994) and Li and } \\
\text { Zhang (1997) }\end{array}$ \\
\hline Li and Zhang model & $\begin{array}{l}S_{\mathrm{H} \max }=\frac{\mu}{1-\mu}\left(S_{\mathrm{v}}-\alpha P_{\mathrm{o}}\right)+\alpha P_{\mathrm{o}}+\frac{E K_{\mathrm{H}}\left(S_{\mathrm{v}}-\alpha P_{\mathrm{o}}\right)}{1+\mu}+\frac{\alpha^{\mathrm{T}} E \Delta T}{1-\mu} \\
S_{\mathrm{hmin}}=\frac{\mu}{1-\mu}\left(S_{\mathrm{v}}-\alpha P_{\mathrm{o}}\right)+\alpha P_{\mathrm{o}}+\frac{E K_{\mathrm{h}}\left(S_{\mathrm{v}}-\alpha P_{\mathrm{o}}\right)}{1+\mu}+\frac{\alpha^{\mathrm{T} E \Delta T}}{1-\mu} \\
S_{\mathrm{H} \max }=\frac{\mu}{1-\mu}\left(S_{\mathrm{v}}-\alpha P_{\mathrm{o}}\right)+\alpha P_{\mathrm{o}}+\frac{E K_{\mathrm{H}}\left(S_{\mathrm{v}}-\alpha P_{\mathrm{o}}\right)}{1+\mu}+\frac{\alpha^{\mathrm{T}} E \Delta T}{1-\mu}+\Delta S_{\mathrm{H}} \\
S_{\mathrm{h} \min }=\frac{\mu}{1-\mu}\left(S_{\mathrm{v}}-\alpha P_{\mathrm{o}}\right)+\alpha P_{\mathrm{o}}+\frac{E K_{\mathrm{h}}\left(S_{\mathrm{v}}-\alpha P_{\mathrm{o}}\right)}{1+\mu}+\frac{\alpha^{\mathrm{T}} E \Delta T}{1-\mu}+\Delta S_{\mathrm{h}}\end{array}$ & $\begin{array}{l}\text { Hydraulic fractures are vertical, } \\
\text { and the minimum stress is in the } \\
\text { horizontal direction } \\
\text { Hydraulic fractures are horizontal, } \\
\text { and the minimum stress is in the } \\
\text { vertical direction }\end{array}$ & Li and Zhang (1997) \\
\hline $\begin{array}{l}\text { Schlumberger } \\
\text { model }\end{array}$ & $\begin{array}{l}S_{\mathrm{Hmax}}=\frac{\mu}{1_{1}-\mu} S_{\mathrm{v}}-2 \gamma P_{\mathrm{o}}+\frac{E \varepsilon_{\mathrm{H} 2}+\mu E \varepsilon_{\mathrm{H} 1}}{E \varepsilon_{\mathrm{h}} 2 \bar{\mu} \boldsymbol{E}_{\varepsilon_{\mathrm{h} 1}}^{2}} \\
S_{\mathrm{hmin}}=\frac{1-\mu}{1-\mu} S_{\mathrm{v}}-2 \gamma P_{\mathrm{o}}+\frac{\mu^{2}}{10}\end{array}$ & $\begin{array}{l}\text { Considering the uniformity of } \\
\text { horizontal stresses and the effect } \\
\text { of Young's modulus }\end{array}$ & $\begin{array}{l}\text { After Yin et al. } \\
\text { (2017) }\end{array}$ \\
\hline
\end{tabular}

$S_{\text {Hmax }}$, horizontal maximum principal stress; $S_{\text {hmin }}$, horizontal minimum principal stress; $S_{\mathrm{v}}$, vertical stress; $\alpha$, Biot coefficient; $\mu$, Poisson's ratio; $K$, skeleton stress coefficient; $P_{\mathrm{o}}$, pore pressure; $\beta_{1}$ and $\beta_{2}$, coefficients reflecting the horizontal maximum and minimum tectonic stress, respectively; $\varepsilon_{\mathrm{H}}$ and $\varepsilon_{\mathrm{h}}$, rock strain in the direction of the horizontal maximum and minimum principal stress, respectively; $E$, Young's modulus; $K_{\mathrm{H}}$ and $K_{\mathrm{h}}$, tectonic stress coefficient in the horizontal maximum and minimum principal stress direction, respectively; $\Delta T$, formation temperature variation; $\alpha^{\mathrm{T}}$, rock linear expansion coefficient; $\Delta S_{\mathrm{H}}$ and $\Delta S_{\mathrm{h}}$, in situ stress additional quantity in the horizontal maximum and minimum principal stress direction, respectively; $\gamma$, a coefficient that is relevant with Biot coefficient and Poisson's ratio

Table 2 The classification of pore pressure (after Du et al. 1995)

\begin{tabular}{lll}
\hline Types & $\begin{array}{l}\text { Pressure coef- } \\
\text { ficient }\end{array}$ & $\begin{array}{l}\text { Pressure gradient, } \\
\mathrm{kPa} / \mathrm{m}\end{array}$ \\
\hline Abnormally low pressure & $<0.96$ & $<9.28$ \\
Normal pressure & $0.96-1.06$ & $9.28-10.41$ \\
Abnormally high pressure & $1.06-1.38$ & $10.41-13.58$ \\
Ultrahigh pressure & $>1.38$ & $>13.58$ \\
\hline
\end{tabular}

$\mu_{\mathrm{s}}=1.5809 \mu_{\mathrm{d}}-0.0880$

$E_{\mathrm{s}}=0.1316 E_{\mathrm{d}}+19.5700$

where $E_{\mathrm{d}}$ and $E_{\mathrm{s}}$ are the dynamic and static Young's modulus, respectively, and $\mu_{\mathrm{d}}$ and $\mu_{\mathrm{s}}$ are the dynamic and static Poisson's ratio, respectively.

\subsection{Model calibration}

The $\varepsilon_{\mathrm{H}}$ and $\varepsilon_{\mathrm{h}}$ for the Chang 7 reservoir in the combined spring model are calibrated with measured data derived from extended leak-off tests (XLOTs) (Table 4) based on Eqs. 7 and 8 (Bredehoeft et al. 1976; White et al. 2002; Zoback et al. 2003; Ju et al. 2017).

$S_{\mathrm{hmin}}=P_{\mathrm{c}}$

$S_{\mathrm{Hmax}}=3 S_{\mathrm{hmin}}-P_{\mathrm{r}}-P_{\mathrm{o}}$

where $S_{\text {Hmax }}$ and $S_{\text {hmin }}$ are the horizontal maximum and minimum stress, respectively, $P_{\mathrm{c}}$ is the shut-in pressure, $P_{\mathrm{o}}$ is the pore pressure, and $P_{\mathrm{r}}$ is the reopening pressure at which closed fractures begin to reopen during repeated pressurization.

Therefore, the average $\varepsilon_{\mathrm{H}}$ and $\varepsilon_{\mathrm{h}}$ for the Chang 7 reservoir can be calculated based on Eqs. 7 and 8, combined spring 
Table 3 The comparison of rock mechanics between experiments and calculations within the Yanchang Formation Chang 7 shale reservoir of Ordos Basin

\begin{tabular}{|c|c|c|c|c|c|c|c|}
\hline \multirow[t]{2}{*}{ Well } & \multirow[t]{2}{*}{ Burial depth, m } & \multicolumn{2}{|c|}{ Young's modulus, GPa } & \multirow[t]{2}{*}{ Error, \% } & \multicolumn{2}{|c|}{ Poisson's ratio } & \multirow[t]{2}{*}{ Error, \% } \\
\hline & & Experiment & Calculation & & Experiment & Calculation & \\
\hline M40 & 2224.95 & 25.114 & 25.817 & 2.80 & 0.237 & 0.252 & 6.28 \\
\hline N76 & 1722.31 & 24.868 & 25.179 & 1.25 & 0.270 & 0.269 & 0.27 \\
\hline N78 & 1625.70 & 25.000 & 25.338 & 1.35 & 0.305 & 0.239 & 21.56 \\
\hline N78 & 1675.35 & 23.984 & 25.505 & 6.34 & 0.260 & 0.258 & 0.69 \\
\hline W67 & 2045.39 & 26.425 & 25.127 & 4.91 & 0.254 & 0.239 & 5.81 \\
\hline W98 & 1967.70 & 31.500 & 24.943 & 20.82 & 0.270 & 0.253 & 6.12 \\
\hline X65 & 1734.60 & 26.744 & 25.624 & 4.19 & 0.227 & 0.257 & 13.06 \\
\hline X67 & 1757.34 & 21.762 & 25.456 & 16.97 & 0.244 & 0.231 & 5.19 \\
\hline X69 & 1886.90 & 28.736 & 25.412 & 11.57 & 0.241 & 0.244 & 1.24 \\
\hline Zn284 & 2095.15 & 24.194 & 25.170 & 4.04 & 0.258 & 0.250 & 2.98 \\
\hline
\end{tabular}

Table 4 Statistical results of the measured and predicted present-day in situ stress magnitudes within the Yanchang Formation of Ordos Basin

\begin{tabular}{|c|c|c|c|c|c|c|c|}
\hline \multirow[t]{2}{*}{ Well } & \multirow[t]{2}{*}{ Burial depth, m } & \multicolumn{2}{|l|}{$S_{\text {Hmax }}, \mathrm{MPa}$} & \multirow[t]{2}{*}{ Error, \% } & \multicolumn{2}{|l|}{$S_{\mathrm{hmin}}, \mathrm{MPa}$} & \multirow[t]{2}{*}{ Error, \% } \\
\hline & & Measured data & Predicted data & & Measured data & Predicted data & \\
\hline \multirow[t]{4}{*}{ Zu131 } & 1514.12 & 32.64 & 33.741 & 3.373 & 26.79 & 28.086 & 4.838 \\
\hline & 1517.00 & 31.88 & 34.040 & 6.775 & 25.31 & 27.829 & 9.953 \\
\hline & 1687.67 & 35.32 & 32.610 & 7.673 & 28.08 & 26.737 & 4.782 \\
\hline & 1688.00 & 35.41 & 32.605 & 7.923 & 28.11 & 26.746 & 4.852 \\
\hline \multirow[t]{3}{*}{ Zu115 } & 1817.40 & 38.17 & 37.357 & 2.131 & 31.35 & 30.991 & 1.144 \\
\hline & 1855.20 & 34.13 & 33.747 & 1.122 & 28.06 & 28.299 & 0.852 \\
\hline & 1866.60 & 39.20 & 35.079 & 10.512 & 30.97 & 28.252 & 8.775 \\
\hline Y410 & 2250.00 & 39.92 & 41.224 & 3.266 & 33.92 & 36.400 & 7.311 \\
\hline Y296 & 2190.10 & 38.61 & 39.166 & 1.439 & 33.51 & 31.937 & 4.694 \\
\hline \multirow[t]{5}{*}{ Y297 } & 2145.08 & 43.24 & 40.125 & 7.204 & 36.87 & 31.676 & 14.088 \\
\hline & 2155.14 & 36.04 & 37.893 & 5.143 & 28.17 & 30.141 & 6.996 \\
\hline & 2158.37 & 40.59 & 39.090 & 3.695 & 35.58 & 31.214 & 12.272 \\
\hline & 2164.44 & 34.25 & 38.528 & 12.489 & 28.98 & 30.832 & 6.389 \\
\hline & 2172.79 & 33.28 & 38.533 & 15.785 & 26.59 & 30.809 & 15.867 \\
\hline
\end{tabular}

model and those measured stress data in Table 4, and the magnitudes are $\varepsilon_{\mathrm{H}}=0.5717$ and $\varepsilon_{\mathrm{h}}=0.2811$, respectively.

\subsection{Pore pressure within the Chang 7 reservoir}

Based on measured pore pressure data from Li et al. (2013) and Duan et al. (2014), the average pressure coefficient within the Chang 7 reservoir ranges between 0.70 and 0.83. Therefore, currently, the Yanchang Formation Chang 7 shale oil reservoir of Ordos Basin experiences the abnormally low pressure.

\section{Stress distribution within the Chang 7 shale reservoir}

\subsection{Vertical distribution of present-day in situ stresses}

Based on the combined spring model for Chang 7 reservoir in this study, error analysis is carried out in this study, and results indicate that the errors between measured and predicted $S_{\mathrm{Hmax}}$ and $S_{\mathrm{hmin}}$ are generally less than $15 \%$ with the majority lower than $10 \%$ (Table 4 ). 
Therefore, the one-dimensional mechanical earth model can be conducted for the Chang 7 shale reservoir and the vertical distribution of present-day in situ stresses is predicted (Fig. 5). Generally, within the Yanchang Formation Chang 7 shale oil reservoir of Ordos Basin, the $S_{\mathrm{Hmax}}, S_{\mathrm{hmin}}$ and $S_{\mathrm{v}}$ magnitudes all increase with burial depth. Overall, they follow the relationship $S_{\mathrm{v}} \geq S_{\mathrm{H} \max } \geq S_{\mathrm{hmin}}$, indicating a dominant normal faulting stress regime (Fig. 5). The results are consistent with those actual stress measurements in the southwestern parts of the studied region (Wang et al. 2014).

\subsection{Lateral distribution of present-day in situ stresses}

In this study, totally, the vertical distribution of stress magnitudes in the Chang 7 shale reservoir was conducted and analyzed in 101 wells. In the following, the study area is divided into $93 \times 100$ grids, and the average stress magnitude of $S_{\mathrm{Hmax}}, S_{\mathrm{hmin}}$ and $S_{\mathrm{v}}$ for each grid is interpolated using the Kriging method based on stress values from adjacent wells. Therefore, the lateral distribution of present-day stresses within the Yanchang Formation Chang $7_{1}$, Chang $7_{2}$ and Chang $7_{3}$ sublayer can be obtained and analyzed (Figs. 6, 7 and 8).

The $S_{\text {Hmax }}$ magnitude varies in the interval of 26-46 MPa, 27-46 MPa and 24-47 MPa within the Chang $7_{1}$, Chang $7_{2}$ and Chang $7_{3}$ sublayer, respectively (Figs. 6, 7 and 8). The $S_{\text {hmin }}$ magnitude ranges $21-38 \mathrm{MPa}$, 22-40 MPa and 21-43 MPa in the Chang $7_{1}$, Chang $7_{2}$ and Chang $7_{3}$ sublayer, respectively (Figs. 6, 7 and 8). The $S_{\mathrm{v}}$ magnitude indicates 22-62 MPa, 24-64 MPa and 24-64 MPa within the Chang $7_{1}$, Chang $7_{2}$ and Chang $7_{3}$ sublayer, respectively (Figs. 6, 7 and 8). Generally, stress distributions in all three sublayers of Yanchang Formation Chang 7 shale oil reservoir indicate similar characteristics with higher and lower stress values located in the northwestern and southeastern regions of the studied region (Figs. 6, 7 and 8).

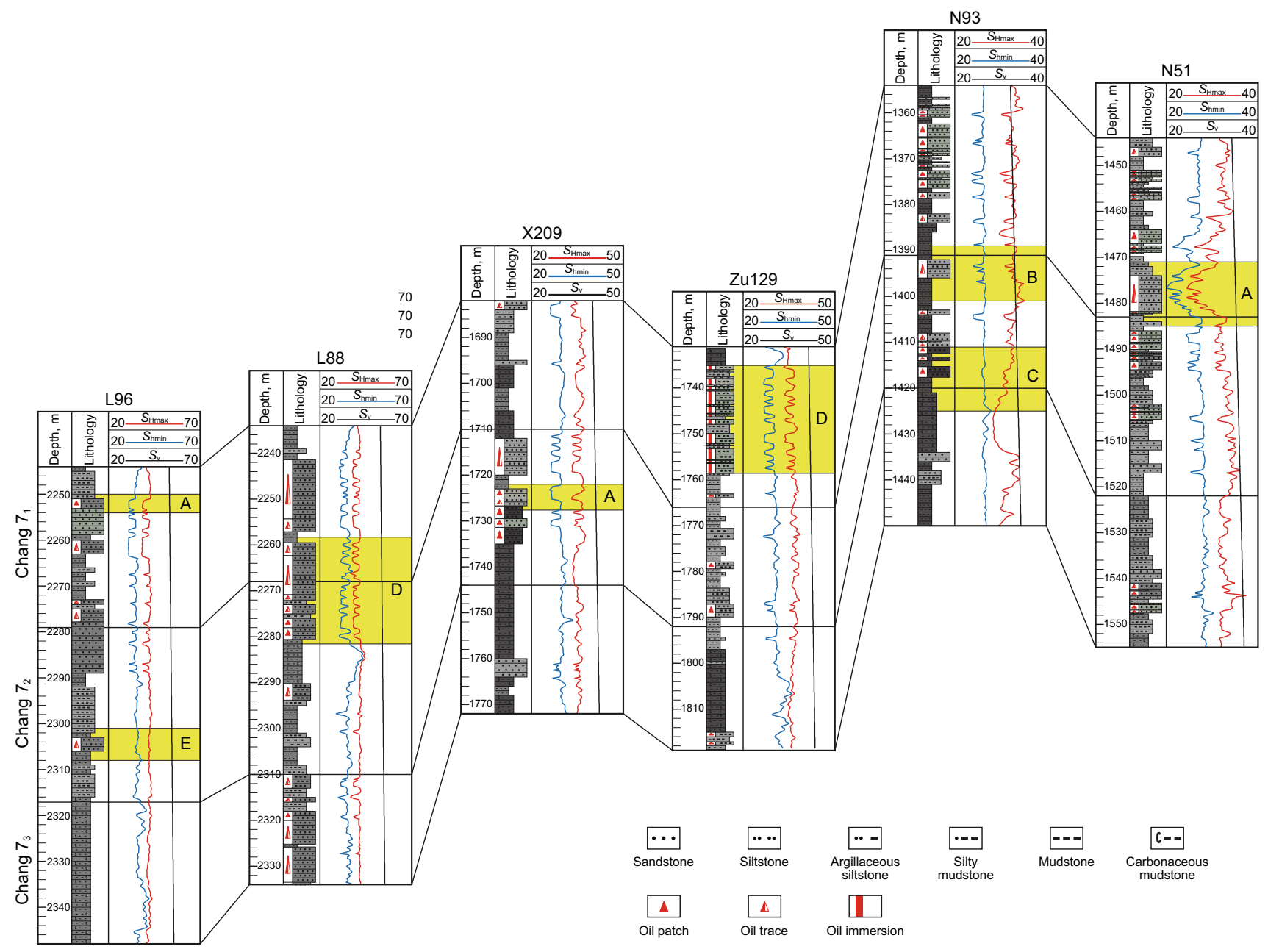

Fig. 5 Vertical distribution of present-day in situ stress magnitudes within the Yanchang Formation Chang 7 shale oil reservoir of Ordos Basin. The locations of these wells are marked in Figs. 6, 7 and 8. Stress unit: MPa 

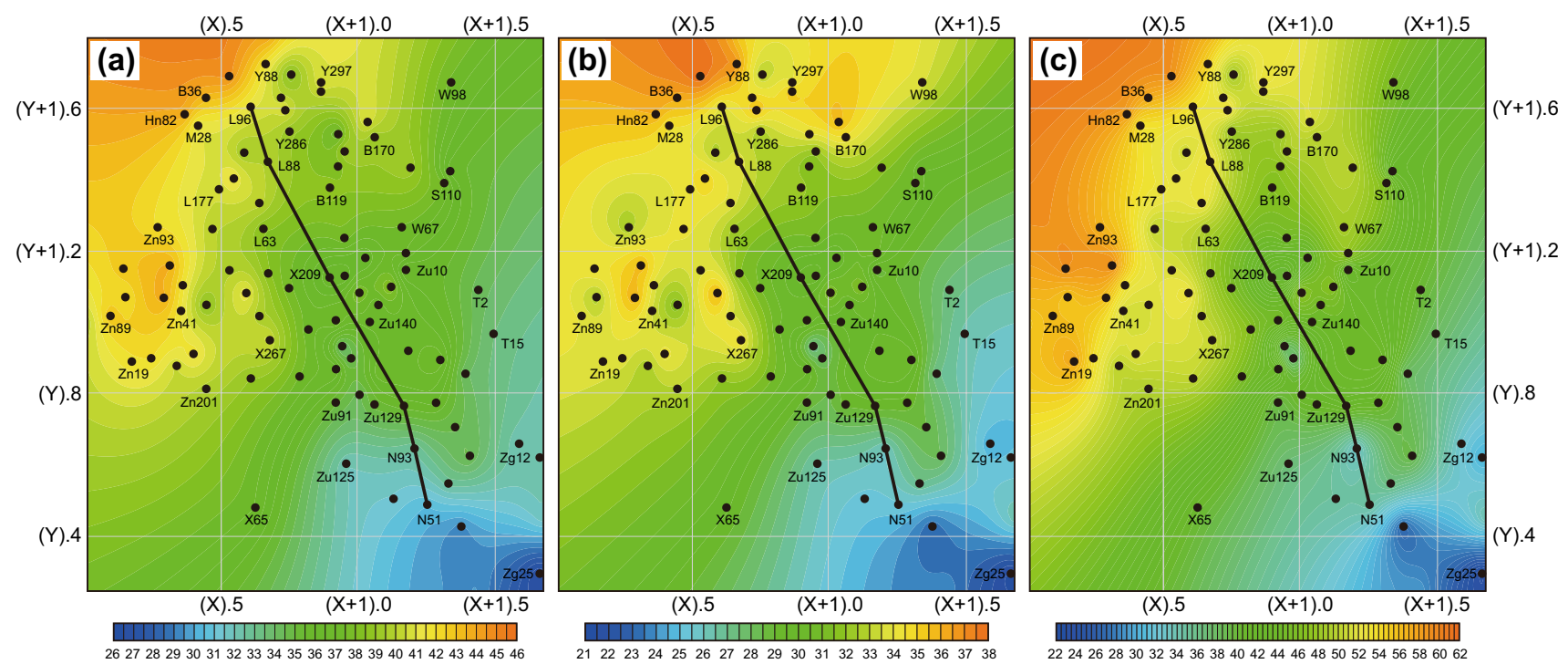

Fig. 6 Lateral distribution of present-day in situ stress magnitudes within the Yanchang Formation Chang $7_{1}$ sublayer of Ordos Basin. a $S_{\text {Hmax }}$, b $S_{\mathrm{hmin}}$ and $\mathbf{c} S_{\mathrm{v}}$. Stress unit: $\mathrm{MPa}$
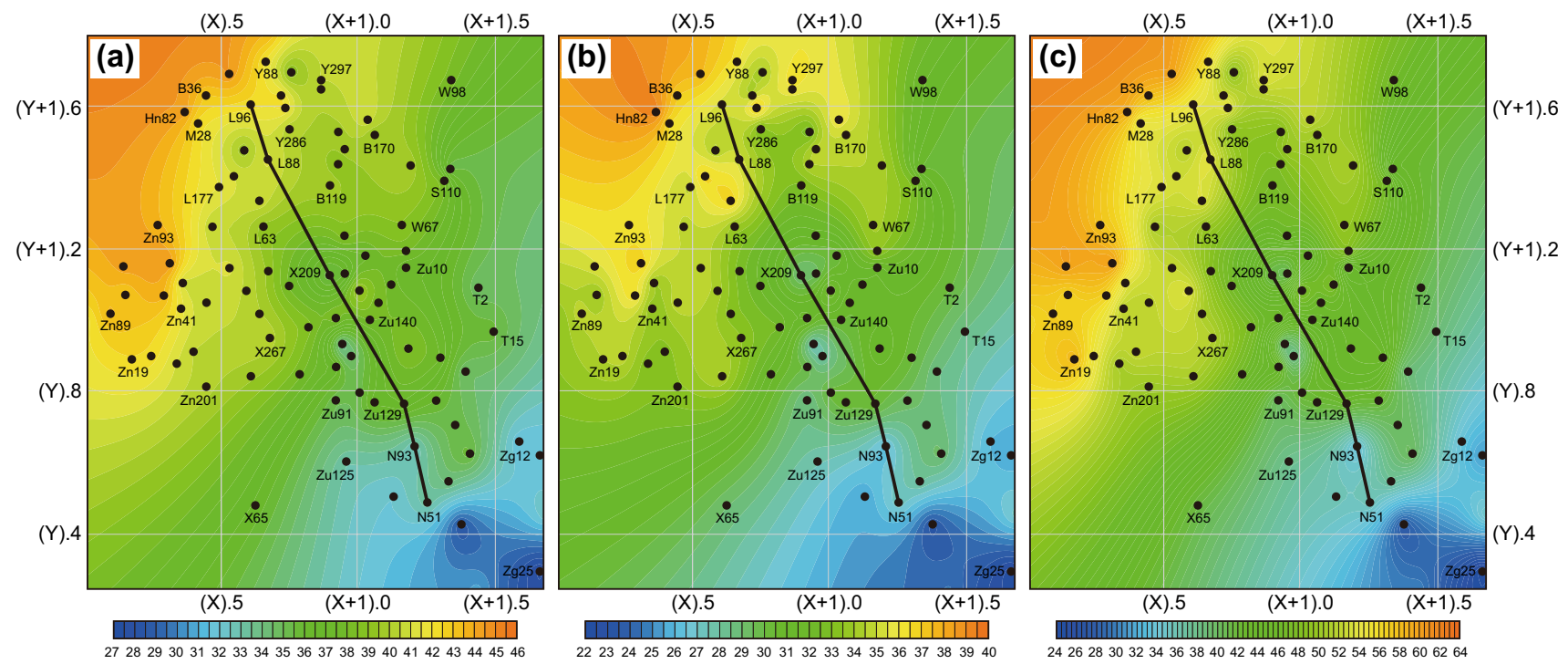

Fig. 7 Lateral distribution of present-day in situ stress magnitudes within the Yanchang Formation Chang $7_{2}$ sublayer of Ordos Basin. a $S_{\text {Hmax }}$, b $S_{\text {hmin }}$ and $\mathbf{c} S_{\mathrm{v}}$. Stress unit: MPa

\section{Discussions}

\subsection{Factors influencing stress distribution}

The factor of burial depth indicates an important control on present-day in situ stress distribution. In this study, the relationship between stress magnitude in top Chang $7_{1}$, Chang $7_{2}$ and Chang $7_{3}$ sublayer and the corresponding burial depth is conducted to analyze the effect of burial depth on stress distribution (Fig. 9). Obviously, for the
Yanchang Formation Chang 7 shale oil reservoir of Ordos Basin, both the $S_{\mathrm{H} \max }$ and $S_{\mathrm{hmin}}$ magnitudes show the linear relationships with burial depth (Eqs. 9 and 10).

$S_{\text {Hmax }}=0.0117 h+15.2490 \quad R^{2}=0.8997$

$S_{\mathrm{hmin}}=0.0107 h+11.4290 \quad R^{2}=0.8147$

where $S_{\mathrm{Hmax}}$ and $S_{\mathrm{hmin}}$ are the horizontal maximum and minimum principal stress, respectively, $h$ indicates the burial depth, and $R$ is the correlation coefficient. 

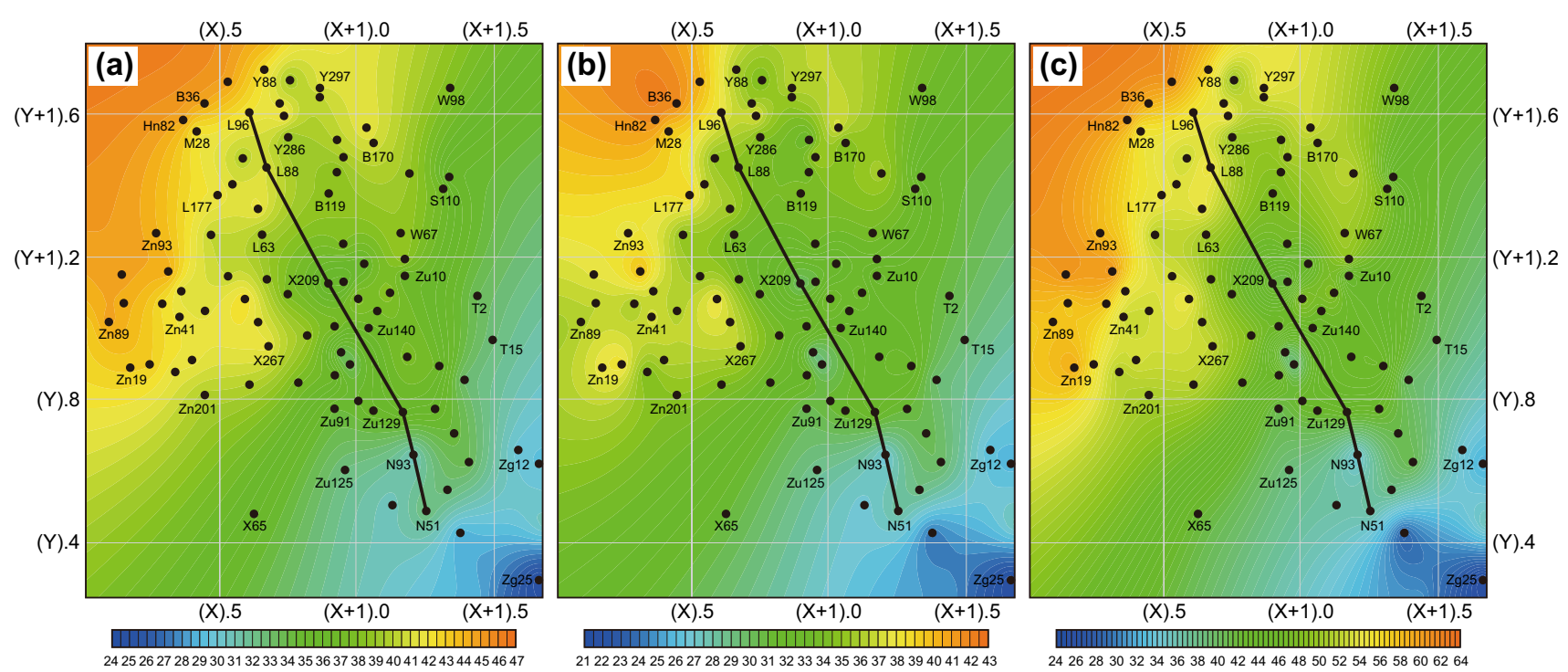

Fig. 8 Lateral distribution of present-day in situ stress magnitudes within the Yanchang Formation Chang $7_{3}$ sublayer of Ordos Basin. a $S_{\text {Hmax }}$, b $S_{\mathrm{hmin}}$ and $\mathbf{c} S_{\mathrm{v}}$. Stress unit: $\mathrm{MPa}$
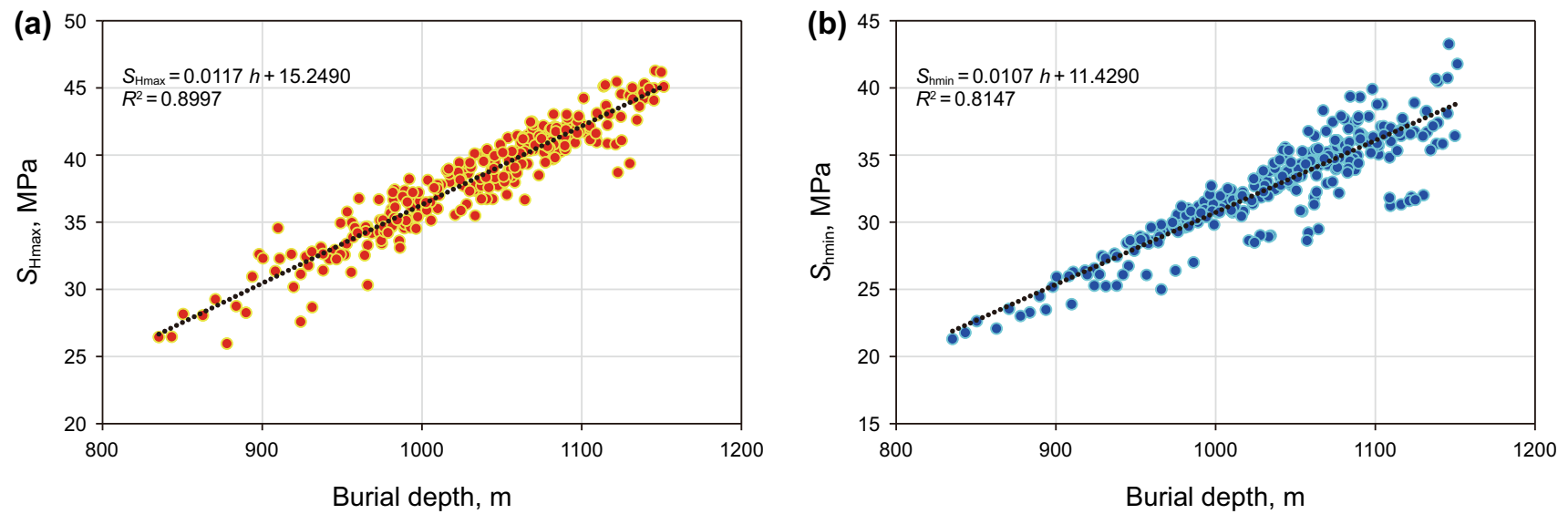

Fig. 9 The relationship between present-day in situ stress magnitudes and burial depth within the Yanchang Formation Chang 7 shale oil reservoir of Ordos Basin

The studied region of Ordos Basin is a tectonically stable area; hence, the stress distribution is largely controlled by lithological changes (rock mechanics) due to the lack of faults and folds (Zoback et al. 2003; Zhou et al. 2007; Ju et al. 2015). Therefore, in this study, the relationship between rock Young's modulus and stress magnitude is analyzed to understand rock mechanics on stress distribution. The selected data for analysis are mainly from Wells Zu131, Zu115, Y410, Y296 and Y297 because these wells have both measured and predicted stress magnitudes. In addition, to avoid the effect of burial depth and Poisson's ratio on the results, the Poisson's ratio is fixed within a small scale ranging between 0.200 and 0.205 . The burial depth for selected data is divided into two segments: $1533.25-1783.75 \mathrm{~m}$ and 2187.00-2351.25 m.

The results indicate that stress magnitudes increase with Young's modulus (Fig. 10), suggesting that rock Young's modulus exhibits a significant effect on stress transfer through the reservoir and that the stiffer rocks commonly conveyed higher stress magnitudes. In addition, the differential stress between $S_{\mathrm{Hmax}}$ and $S_{\mathrm{hmin}}$ is an important parameter in hydraulic fracturing. Low differential stress can commonly produce a complex hydraulic fracture system (Zhou et al. 2007; Ju et al. 2018). Obviously, the horizontal differential stress becomes higher with the increase in Young's modulus in the Yanchang Formation Chang 7 

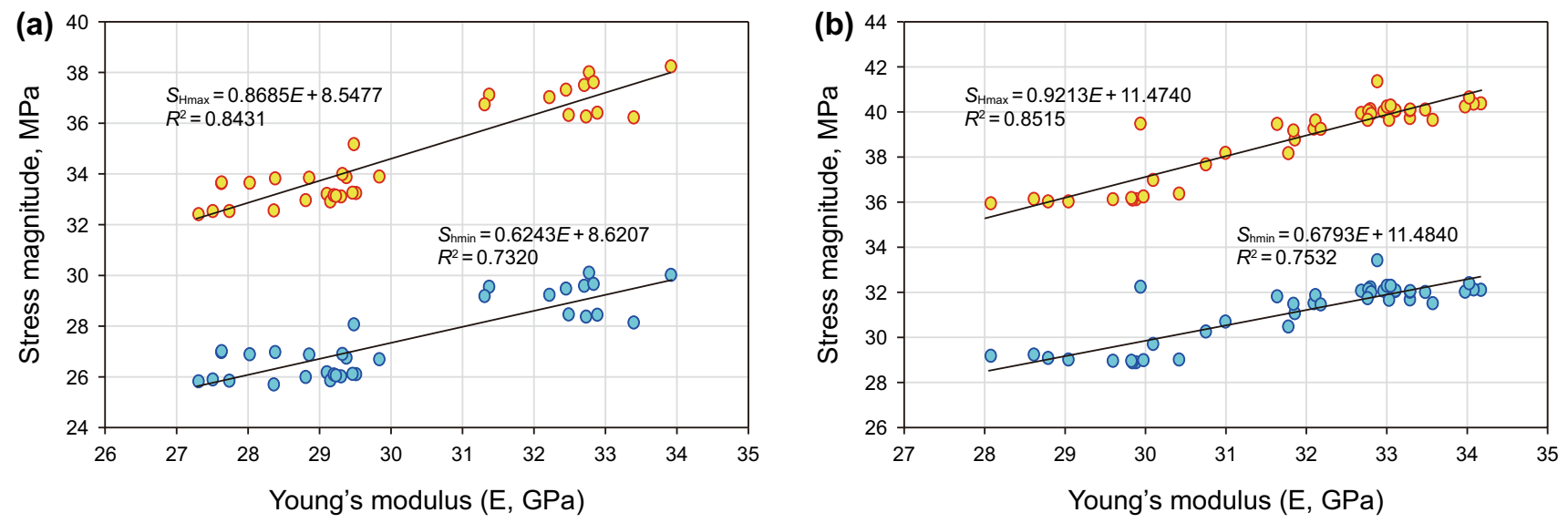

Fig. 10 The effect of Young's modulus on present-day in situ stress field within the Yanchang Formation Chang 7 shale oil reservoir of Ordos Basin. a burial depth of 1533.25-1783.75 m, b burial depth of 2187.00-2351.25 m

reservoir (Fig. 10); hence, relatively high Young's modulus will result in simple hydraulic fracture systems.

\subsection{Vertical stress pattern}

The magnitudes of in situ stress vary greatly with burial depth in the Yanchang Formation Chang 7 reservoir (Fig. 5), which is mainly caused by the difference in rock mechanics parameters, especially the Young's modulus. Based on Zhou et al. (2007), there are mainly five types of vertical stress patterns (A-E), all of which are present in the Chang 7 shale oil reservoir of Ordos Basin (Fig. 5):

Type A: high-low-high (HLH). Stress magnitudes in the roof and floor layers are much higher than those in the target fracturing layer. Vertical propagation of hydraulic fractures in this stress pattern will be largely limited due to the relatively high stress difference between layers.

Type B: low-low-high (LLH). Stress magnitudes in the roof and target fracturing layers are generally close to each other, but are lower than those in the floor layer. The upward propagation of hydraulic fractures is easily in this pattern.

Type C: high-low-low (HLL). Stress magnitudes in the floor and target fracturing layers are generally close to each other, but are lower than those in the roof layer. The downward propagation of hydraulic fractures is easily in this pattern.

Type D: interbedded. Stress magnitudes change frequently in all layers. Hydraulic fractures can propagate both upward and downward.

Type E: uniform. Stress magnitudes are generally unchanged in all layers. Hydraulic fractures can also propagate both upward and downward.

Vertical stress pattern is critical for understanding the vertical propagation of hydraulic fractures in layered media. Therefore, with accurate assessments of vertical stress pattern, the scale of hydraulic fracturing and the development of well network can be determined rationally (Feng et al. 2019).

\section{Conclusions}

In this study, the present-day in situ stress distribution within the Yanchang Formation Chang 7 shale oil reservoir is predicted based on well logs calibrated with measured data using the combined spring model. The effects of burial depth and Young's modulus on stress distribution are also analyzed. The results in this study are expected to provide some new geological references for the exploration and development of shale oil within the Yanchang Formation Chang 7 oil-bearing layer of the Ordos Basin.

Generally, the following results and conclusions can be obtained:

1. In this study, a one-dimensional mechanical earth model is conducted, and the results indicate that the $S_{\mathrm{H} \max }$, $S_{\mathrm{hmin}}$ and $S_{\mathrm{v}}$ magnitudes all increase with burial depth, and a dominant normal faulting stress regime is in the Yanchang Formation Chang 7 shale oil reservoir of Ordos Basin.

2. In the studied region, relatively high and low present-day stress magnitudes are distributed in the northwestern and southeastern regions, respectively.

3. The factor of burial depth indicates a linear relationship with burial depth; a larger burial depth results in a higher stress magnitude.

4. Rock Young's modulus shows a great effect on the present-day stress distribution. Larger Young's moduli produce higher stress magnitudes. In addition, the horizontal differential stress will become higher with 
the increase in Young's modulus, resulting in simple hydraulic fracture systems.

\begin{abstract}
Acknowledgements The authors would like to thank the anonymous reviewers for offering their constructive suggestions and comments, which have improved this manuscript in many aspects. The financial supports are from the National Natural Science Foundation of China (41702130 and 41971335), China Postdoctoral Science Foundation (2017T100419 and 2019M660269) and Priority Academic Program Development of Jiangsu Higher Education Institutions (PAPD).
\end{abstract}

Open Access This article is licensed under a Creative Commons Attribution 4.0 International License, which permits use, sharing, adaptation, distribution and reproduction in any medium or format, as long as you give appropriate credit to the original author(s) and the source, provide a link to the Creative Commons licence, and indicate if changes were made. The images or other third party material in this article are included in the article's Creative Commons licence, unless indicated otherwise in a credit line to the material. If material is not included in the article's Creative Commons licence and your intended use is not permitted by statutory regulation or exceeds the permitted use, you will need to obtain permission directly from the copyright holder. To view a copy of this licence, visit http://creativecommons.org/licenses/by/4.0/.

\section{References}

Anderson EM. The dynamics of faulting and dyke formation with applications to Britain. 2nd ed. Edinburgh: Oliver; 1951.

Anderson RA, Ingram DS, Zanier AM. Determining fracture pressure gradients from well logs. J Pet Technol. 1973;25:1259-68. https ://doi.org/10.2118/4135-PA.

Bell JS. Petro geoscience 2. In situ stresses in sedimentary rocks (part 2): applications of stress measurements. Geosci Can. 1996;23(3):135-53.

Binh NTT, Tokunaga T, Son HP, Van Binh M. Present-day stress and pore pressure fields in the Cuu Long and Nam Con Son Basins, offshore Vietnam. Mar Pet Geol. 2007;24:607-15. https://doi. org/10.1016/j.marpetgeo.2007.04.002.

Bredehoeft JD, Wolff RG, Keys WS, Shuter E. Hydraulic fracturing to determine regional in situ stress field, Piceance Basin, Colorado. Geol Soc Am Bull. 1976;87(2):250-8. https://doi. org/10.1130/0016-7606(1976)87\%3c250:hftdtr\%3e2.0.co;2.

Brooke-Barnett S, Flottmann T, Paul PK, Busetti S, Hennings P, Reid R et al. Influence of basement structures on in situ stresses over the Surat Basin, southeast Queensland. J Geophys Res Solid Earth. 2015;120:4946-65. https://doi.org/10.1002/2015JB011964.

Cui JW, Zhu RK, Luo Z, Li S. Sedimentary and geochemical characteristics of the Triassic Chang 7 Member shale in the southeastern Ordos Basin, central China. Pet Sci. 2019;16:285-97. https://doi. org/10.1007/s12182-019-0307-9.

Dinnik AN. On rock pressure and calculating the vertical shaft support. Inzh Rob. 1925;7:1-12 (in Russian).

Du X, Zheng HY, Jiao XQ. Abnormal pressure and hydrocarbon accumulation. Earth Sci Front. 1995;2(3-4):137-48. https://doi. org/10.3321/j.issn:1005-2321.1995.04.002 (in Chinese).

Duan Y, Cao XX, Zhao Y. Characteristics and formation mechanism of Mesozoic underpressured reservoirs in Ordos Basin. Earth Sci. 2014;39(3):341-9. https://doi.org/10.3799/dqkx.2014.032 (in Chinese).
Eaton BA. Fracture gradient prediction and its application in oilfield operation. Soc Pet Eng. 1969;21(10):1353-60. https://doi. org/10.2118/2163-PA.

Eaton BA. Graphical method predicts geopressures worldwide. World Oil. 1972;182(6):51-6.

Engelder T. Stress regimes in the lithosphere. Princeton: Princeton University Press; 1993.

Fjaer E, Holt RM, Horsrud P, Horsrud P. Petroleum related rock mechanics. 2nd ed. London: Elsevier; 2008.

Feng JW, Shang L, Li XZ, Luo P. 3D numerical simulation of heterogeneous in situ stress field in low-permeability reservoirs. Pet Sci. 2019;16:939-55. https://doi.org/10.1007/s12182-019-00360-w.

Fu JH, Yu J, Xu LM, Xiaobing N, Shengbin F, Xiujuan W et al. New progress in exploration and development of tight oil in Ordos Basin and main controlling factors of large-scale enrichment and exploitable capacity. China Pet Explor. 2015;20(5):9-19. https ://doi.org/10.3969/j.issn.1672-7703.2015.05.002 (in Chinese).

Huang RZ. A model for predicting formation fracture pressure. J China Pet Inst. 1984;4:335-47 (in Chinese).

Jia CZ, Zheng M, Zhang YF. Unconventional hydrocarbon resources in China and the prospect of exploration and development. Pet Explor Dev. 2012;39(2):139-46. https://doi.org/10.1016/s1876 -3804(12)60026-3.

Ju W, Jiang B, Miao Q, Wang J, Qu Z, Li M. Variation of in situ stress regime in coal reservoirs, eastern Yunnan region, South China: implications for coalbed methane production. AAPG Bull. 2018;102(11):2283-303. https://doi.org/10.1306/04241817376.

Ju W, Jiang B, Qin Y, Wu C, Wang G, Qu Z, et al. The present-day in situ stress field within coalbed methane reservoirs, Yuwang Block, Laochang Basin, south China. Mar Pet Geol. 2019;102:6173. https://doi.org/10.1016/j.marpetgeo.2018.12.030.

Ju W, Niu XB, Feng SB, You Y, Xu K, Wang G, et al. Presentday in situ stress field within the Yanchang Formation tight oil reservoir of Ordos Basin, central China. J Pet Sci Eng. 2020;187:106809. https://doi.org/10.1016/j.petrol.2019.106809.

Ju W, Shen J, Qin Y, Wu C, Shen Y, Yang Z, et al. In-situ stress state in the Linxing region, eastern Ordos Basin, China: implications for unconventional gas exploration and production. Mar Pet Geol. 2017;86:66-78. https://doi.org/10.1016/j.marpetgeo.2017.05.026.

$\mathrm{Ju}$ W, Sun WF, Hou GT. Insights into the tectonic fractures in the Yanchang Formation interbedded sandstone-mudstone of the Ordos Basin based on core data and geomechanical models. Acta Geol Sin (Engl). 2015;89(6):1986-97. https://doi.org/10.1111/17556724.12612.

Li SX, Shi ZJ, Liu XY, Shiyu Y, Xiuqin D, Guanglin LI, et al. Quantitative analysis of the Mesozoic abnormally low pressure in Ordos Basin. Pet Explor Dev. 2013;40(5):566-71. https://doi. org/10.1016/s1876-3804(13)60074-9.

Li ZM, Zhang JZ. In-situ stress and petroleum exploration and development. Beijing: Petroleum Industry Press; 1997 (in Chinese).

Lyu WY, Zeng LB, Liu ZQ, Liu G, Zu K. Fracture responses of conventional logs in tight-oil sandstones: a case study of the Upper Triassic Yanchang Formation in southwest Ordos Basin, China. AAPG Bull. 2016;100(9):1399-417. https://doi.org/10.1306/0404161512 9.

Matthews WR, Kelly J. How to predict formation pressure and fracture gradient. Oil Gas J. 1967;65:92-106.

Newberry BM, Nelson RF, Ahmed U. Prediction of vertical hydraulic fracture migration using compressional and shear wave slowness. Soc Pet Eng. 1985;13895:1-8. https://doi.org/10.2118/13895-MS.

Rajabi M, Tingay M, Heidbach O. The present-day state of tectonic stress in the Darling Basin, Australia: implications for exploration and production. Mar Pet Geol. 2016;77:776-90. https://doi. org/10.1016/j.marpetgeo.2016.07.021.

Ritts BD, Hanson AD, Darby BJ, Nanson L, Berry A. Sedimentary record of Triassic intraplate extension in North China: 
evidence from the nonmarine NW Ordos Basin, Helan Shan and Zhuozi Shan. Tectonophysics. 2004;386:177-202. https://doi. org/10.1016/j.tecto.2004.06.003.

Schmitt DR, Currie CA, Zhang L. Crustal stress determination from boreholes and rock cores: fundamental principles. Tectonophysics. 2012;580:1-26. https://doi.org/10.1016/j.tecto.2012.08.029.

Sun HQ. Exploration practice and cognitions of shale oil in Jiyang Depression. China Pet Explor. 2017;22(4):1-14. https://doi. org/10.3969/j.issn.1672-7703.2017.04.001 (in Chinese).

Thiercelin MJ, Plumb RA. A core-based prediction of lithologic stress contrasts in east Texas Formation. Soc Pet Eng. 1994;9(4):251-8. https://doi.org/10.2118/21847-PA.

Tingay M, Hills RR, Morley CK, King RC, Swarbrick RE, Damit AR. Present-day stress and neotectonics of Brunei: implications for petroleum exploration and production. AAPG Bull. 2009;93(1):75-100. https://doi.org/10.1306/08080808031.

Vedachalam N, Srinivasalu S, Rajendran G, Ramadass GA, Atmanand M. Review of unconventional hydrocarbon resources in major energy consuming countries and efforts in realizing natural gas hydrates as a future source of energy. J Nat Gas Sci Eng. 2015;26:163-75. https://doi.org/10.1016/j.jngse.2015.06.008.

Wang Y, Yao CY, Gao ZJ, Li JR, Zhu XC. Calculation of geostress by using conventional logging. Xinjiang Oil Gas. 2014;10(1):927. https://doi.org/10.3969/j.issn.1673-2677.2014.01.021 (in Chinese).

White AJ, Traugott MO, Swarbrick RE. The use of leak-off tests as means of predicting minimum in situ stress. Pet Geosci. 2002;8(2):189-93. https://doi.org/10.1144/petgeo.8.2.189.

Yang H, Fu JH, He HQ, Zhaoming W, Haijun Y, Fujie J et al. Formation and distribution of large low-permeability lithologic oil regions in Huaqing, Ordos Basin. Pet Explor Dev. 2012;39(6):683-91. https ://doi.org/10.1016/s1876-3804(12)60093-7.

Yang H, Li SX, Liu XY. Characteristics and resource prospects of tight oil and shale oil in Ordos Basin. Acta Pet Sin. 2013;34(1):1-11. https://doi.org/10.7623/syxb201301001 (in Chinese).

Yang H, Niu XB, Xu LM, Shengbin F, Yuan Y, Liang X, et al. Exploration potential of shale oil in Chang 7 Member, Upper Triassic Yanchang Formation, Ordos Basin, NW China. Pet Explor Dev. 2016;43(4):560-9. https://doi.org/10.1016/s1876-3804(16)30066-0.

Yang Z, Hou LH, Lin SH, Xia L, Lijun Z, Songtao W, et al. Geologic characteristics and exploration potential of tight oil and shale oil in Lucaogou Formation in Jimsar Sag. China Pet Explor. 2018;23(4):76-85. https://doi.org/10.3969/j.issn.16727703.2018.04.009 (in Chinese).

Yin S, Ding WL, Zhou W, Shan Y, Xie R, Guo C, et al. In situ stress field evaluation of deep marine tight sandstone oil reservoir: a case study of Silurian strata in northern Tazhong area, Tarim Basin. NW China. Mar Pet Geol. 2017;80:49-69. https://doi. org/10.1016/j.marpetgeo.2016.11.021.

Zeng LB, Li XY. Fractures in sandstone reservoirs with ultra-low permeability: a case study of the Upper Triassic Yanchang Formation in the Ordos Basin, China. AAPG Bull. 2009;93(4):461-77. https ://doi.org/10.1306/09240808047.

Zhang JC, Lin LM, Li YX, Tang X, Zhu LL, Xing YW, et al. Classification and evaluation of shale oil. Earth Sci Front. 2012;19(5):32231 (in Chinese).

Zhang WZ, Yang H, Yang WW, Wu K, Liu F. Assessment of geological characteristics of lacustrine shale oil reservoir in Chang 7 Member of Yanchang Formation, Ordos Basin. Geochimica. 2015;44(5):505-15. https://doi.org/10.3969/j.issn.03791726.2015.05.010 (in Chinese).

Zhou QF, Jin ZJ, Yang GF, Ning D, Zhucheng S. Shale oil exploration and production in the U.S.: status and outlook. Oil Gas Geol. 2019;40(3):469-77. https://doi.org/10.11743/ogg20190303 (in Chinese).

Zhou W, Yan CH, Wang SZ, Xie RC, Zhang SN, Deng HC et al. The Evaluation Methods for the Present-day In-situ Stress Field in Oil and Gas Reservoirs and its Applications. Beijing: Geological Publishing House; 2007. (in Chinese).

Zhou Z, Yan YP, Ren SM, Jiang C, Liu G, Yin J et al. Prospects and strategy for shale oil exploration in Songliao Basin, China. China Min Mag. 2017;26(3):171-3. https://doi.org/10.3969/j.issn.10044051.2017.03.035 (in Chinese).Zhou W, Yan CH, Wang SZ, Xie RC, Zhang SN, Deng HC, Shan YM, Chen Q, Zhang YD

Zoback MD, Barton CA, Brudy M, Castillo DA, Finkbeiner T, Grollimund BR, et al. Determination of stress orientation and magnitude in deep wells. Int J Rock Mech Min Sci. 2003;40(7-8):1049-76. https://doi.org/10.1016/j.ijrmms.2003.07.001.

Zou CN, Yang Z, Cui JK, Rukai Z, Lianhua H, Shizhen T, et al. Formation mechanism, geological characteristics and development strategy of nonmarine shale oil in China. Pet Explor Dev. 2013;40(1):15-27. https://doi.org/10.1016/s1876-3804(13)60002-6. 